\title{
Circumstantial migration: how Gambian journeys to China enrich migration theory
}

Jørgen Carling ${ }^{\mathrm{a}}$ and Heidi Østbø Haugen ${ }^{\mathrm{b} *}$

${ }^{a}$ Peace Research Institute Oslo (PRIO), Norway; ${ }^{b}$ Department of Culture Studies and Oriental Languages, University of Oslo, Norway

Jørgen Carling

Peace Research Institute Oslo (PRIO)

PO Box 9229 Grønland

NO-0134 Oslo

Norway

Email: jorgen@prio.org

* Corresponding author:

Heidi Østbø Haugen

Department of Culture Studies and Oriental Languages

Postboks 1010 Blindern

NO-0315 OSLO

University of Oslo

Norway

Email: h.o.haugen@ikos.uio.no

\section{Acknowledgements}

The authors thank the Gambian informants for sharing their experiences and interpretations. Fieldwork in Gambia was carried out in collaboration with Manon Diederich at the University of Cologne. The research was supported by the Research Council of Norway (grant number 222410). Haugen benefited from the hospitality of Professor Li Zhigang and the School of Geography and Planning, Sun Yat-sen University, during fieldwork in China. 


\title{
Circumstantial migration: how Gambian journeys to China enrich migration theory
}

\author{
Migration processes are often said to involve elements of choice and \\ constraint in variable measure. However, this bipolar framing may fail to \\ capture the twists and turns in many migrants' erratic lives. In this article, \\ we introduce the concept circumstantial migration to describe how \\ migration trajectories and experiences unfold in unpredictable ways under \\ the influence of micro-level context and coincidence. We expound on the \\ concept through the case study of a cohort of Gambians who travelled to \\ Guangzhou in South China, unexpectedly found that their prospects in \\ China were limited, and struggled to leave the country. Our analysis \\ examines the particularities of the Chinese immigration regime and its \\ effects while presenting a broader argument against Chinese \\ exceptionalism in migration studies. The concept of circumstantial \\ migration underpins the questions guiding the analysis: how do latent \\ influences trigger immediate circumstances? How do migrants engage \\ with volatile circumstances? How are circumstances mediated by a variety \\ of brokers? How does circumstantial migration produce particular \\ temporalities? The core empirical data comes from interviews with \\ returnees in Gambia, though the analysis draws upon extensive \\ ethnographic fieldwork in Guangzhou over the past decade.
}

Keywords: circumstantial migration, The Gambia, China, Chinese immigration policy, temporalities

\section{Introduction}

Two-thirds of all international migrants originate in the Global South. For the majority of these migrants, a place in the Global South is also their destination. Yet, this part of the world accounts for a marginal share of research funding, training, and publications in migration studies. Alongside this widely acknowledged inequality, another, more subtle bias exists, and it has compelled this article: migration flows that do not touch the homelands of Anglophone academia are prone to being cast in an empirical, rather than 
theoretical, light. Migration to, from, and within China is a case in point. In leading textbooks on migration, China plays a marginal role compared to North America and Europe (see, for example, Mavroudi and Nagel 2016; Castles, de Haas, and Miller 2014; Samers and Collyer 2017). However, the geographic bias is by far the most pronounced in the primary textbook on migration theory. The latest edition of Brettell and Hollifield's (2015) Migration Theory: Talking Across Disciplines has more than 150 references to the United States; a sole reference is made to China.

Fifty years ago, the president of the American Historical Association wrotewith tongue in cheek - that American academics have been quick to conclude that they better 'leave Chinese matters to the China expert' (Fairbank 1969, 868). This criticism of Chinese exceptionalism was put forth at a time when China was closed to most foreign scholars and students, and few Chinese scholars published in foreign languages. Today, the situation is radically different, and the sustained tendency to settle for idiosyncratic descriptions of Chinese migration is all the more disconcerting.

In this article, we examine the experiences of a cohort of Gambians who travelled to China with ill-informed expectations that landed them in diverse unforeseen and difficult situations. We draw upon their narratives to develop a general argument about the volatility of migration trajectories and experiences, centred on the concept circumstantial migration.

Gambian overseas migration as well as Chinese reception of foreigners exhibit distinct features. Yet, their context specificity does not render these empirical framings marginal to global knowledge production, suited for colourful documentation rather than theoretical discussion. Rather, all knowledge is provincial in the sense that all theories are developed within specific contexts (Chakrabarty 1992). The role of serendipitous empirical discoveries in the development of social theory is well established in the social sciences (Merton 1948). However, there are global inequalities in whether contingent observations are used as vantage points for theorising with the potential to transcend local contexts, and the tendency to particularise China has been especially strong (Chen 2010).

The next section introduces the concept of circumstantial migration, linking it to other recent development in migration research. Thereafter, we provide a brief background on African migration to China and account for our methods and data. The remainder of the article applies the concept of circumstantial migration to our empirical case, first focusing on the specificities of the Chinese context and then proceeding with 
an empirically informed elaboration of four general arguments concerning migration and circumstance.

\section{Circumstantial migration}

Migration research has engaged with agency and structure as complementary frames of reference. The conceptual pair has been formulated as, on the one hand, agency, choice, or volition, and, on the other, structure, force, or constraint. Most researchers assign explanatory power in migration processes a combination of agency and structure, maintaining the conceptual pair as a central reference frame (e.g. Bakewell 2010; Mainwaring 2016, Feng et al., this issue). The interplay of agency and structure is indeed central for understanding and explaining migration dynamics. At the same time, migrants' lives often take turns that result from neither decisive agency nor structural determination - and not even a combination of the two. Influences beyond the poles of the traditional theoretical dichotomy also help explain whether and how people move or stay.

We propose the concept circumstantial migration to describe migration trajectories and experiences that unfold in unpredictable ways under the influences of coincidence and micro-level context. The concept is not a categorical label for certain migrants or migration flows, but rather a designation that adds to our understanding of how migration takes place and is experienced. In this sense, it is comparable to the notion of 'chain migration', which describes dynamics that may shape diverse migration flows rather than a particular category of migration.

The two reference points in our definition of circumstantial migrationcoincidence and context — are easily understood as fundamentally atheoretical. If something occurs by coincidence — randomly_it seems futile to search for a theoretical explanation. Typical coincidental elements in migration processes include chance encounters with others, good or bad luck at critical junctures, and accidental discovery of opportunities. Context, too, often stands in opposition to theory in the sense that calls for attention to context typically imply that the influence of empirical specifics trumps generalising theoretical postulates. Here, we think of context at the micro-level as the situations in which chance events happen, and which contribute to determining their consequences. 
Circumstantial migration, as an outcome of context and coincidence, is, therefore, a theoretical concept - a heuristic tool for understanding a complex empirical reality. First, it holds potential for understanding twists and turns as constitutive elements of many migration experiences, rather than as 'noise'. Second, it interrogates why circumstance plays a prominent role under certain migration regimes. Third, it invites examination of how plans and serendipities interrelate.

The idea of circumstantial migration intersects with emerging strands of research on 'trajectories' and 'journeys' within migration studies (Schapendonk et al. in press; Mainwaring and Brigden 2016). The spatial framing of this work deviates from the conventional binary of origins and destinations. Circumstantial migration can also mark digressions from the conventional teleological sequence of departure, arrival, settlement, and integration. Moreover, research on trajectories and journeys highlights the unexpected, ambiguous, and erratic aspects of migration experiences. Our contribution broadens the mobilities optic, which includes capacities to aspire and plan, but also fluctuating practices, unintended consequences, and happenstance (cf. Carling and Collins 2018; Zhang 2018).

The uncertain twists and turns of circumstantial migration often translate into subjection of the migrant. Indeed, circumstantial migration may both result from and contribute to migrants' powerlessness vis-à-vis migration regimes as well as other social actors. However, uncertainty can also signify possibility in a positive sense. As Cooper and Pratten $(2014,2)$ write: 'uncertainty is a social resource and can be used to negotiate insecurity, conduct and create relationships, and act as a source for imagining the future with the hopes and fears this entails'. In other words, circumstantial migration might be more at odds with images of migration as a deliberate and well-planned endeavour than as a form of adventure. The element of adventure can be important in all migration, including departures that take place under challenging circumstances (Alpes 2017; Pandolfo 2007; Oumar Ba and Choplin 2005).

The dynamics of Gambian migration to China entails migration experiences that are particularly illustrative of circumstantial migration. The migration reflects the intersection of two contexts with particular characteristics: immigration to China, which we address in a later section, and emigration from West Africa, which is comprehensively examined elsewhere (e.g. Alpes 2016; Conrad-Suso 2019; Gaibazzi 2015a; Hernández-Carretero and Carling 2012). 


\section{Methods}

Our data derives from a decade of ethnographic research on migration and trade between West Africa and South China starting in 2009. The city of Guangzhou is home to the largest African population in Asia. We both lived in Xiaobei, a Guangzhou neighbourhood with a high concentration of African immigrants, for 12 months in 2014 . One of us, Heidi Østbø Haugen, accompanied return migrants and traders to Nigeria, Gambia, Ghana, and Togo on four shorter fieldtrips between 2011 and 2015.

Gambians in China were first interviewed by Haugen in 2009. The second half of 2014 saw a noticeable upturn in the number of Gambians arriving in Guangzhou, mostly of men with aspirations to find work. Another researcher who was doing fieldwork in the city at the time, Manon Diederich, approached Haugen on behalf of the Gambian men to inquire about opportunities for assisted voluntary return. The men were eager to document their experiences, both for their own reference and to warn others, and Diederich and Haugen facilitated this endeavour. In 2015, Haugen went to the Gambia to interview returnees and create an online platform for informationsharing. She carried out semi-structured interviews with 12 returnees from China. Interview notes were organised and coded in NVivo along with data from participant observation. The names used in this article are pseudonyms.

\section{Chinese circumstances}

The experience of the Gambians should be understood within the broader context of international migration to China. Immigration flows to China are tiny in relation to the native population, but they are growing and diversifying, simultaneously reflecting and stimulating the global integration of China's economy (see Zhu and Qian 2020). In the case of Africans, migration to China is also spurred by restrictive immigration policies in Europe, which have diverted prospective migrants towards new and more accessible destinations, including China (Mathews, Lin, and Yang 2017; Haugen 2012; Jordan et al., this issue). Some are drawn to South China by the region's trading opportunities, although a focus on economic prospects alone does not account for the diversity in trajectories and motivations of Africans arriving in China (Lan 2017; Bertoncello and Bredeloup 2009; Haugen 2014).

China's administration and legislation of migration have not changed in pace with developments on the ground. The country's first comprehensive immigration 
legislation was passed in 2012 (Liu 2016). The law introduced harsher penalties for illegal entry, stay, and employment in China. In Guangzhou and neighbouring administrative districts, local branches of the Public Security Bureau (PSB) and individual police officers are motivated by performance statistics and monetary incentives for pushing undocumented migrants out of their precincts or detaining them (Huang 2018). On the one hand, this reflects China's moving towards a relatively streamlined restrictive immigration policy regime, akin to the norm in high-income countries. On the other, the experience of being a foreigner in China is shaped by a range of particular, sometimes confusing circumstances, which we discuss in the next section.

\section{Illegibility of the immigration regime}

Even in a global context where migrants often face bewildering bureaucracies, the Chinese immigration regime is particularly illegible. One perplexing reason is that authorities treat regulation of immigration and foreigners as confidential. As legal scholar Guofu Liu $(2016,12)$ points out, 'the majority of immigration laws, regulations, and policies are internal and not open to public scrutiny'. Another cause for disorientation is that practices vary greatly from place to place, whether between Chinese embassies abroad, points of entry into the country, or cities and counties across China. People adapt to these changes by, for example, applying for visas where embassies are known to be lenient, renewing visas in parts of China with less restrictive practices, and moving to districts where the local PSB is more tolerant of undocumented migrants. In Guangzhou, increasingly restrictive policies towards foreigners has contributed to a recent decline in the number of Africans legally residing in the city (Huang 2018; Liang and Le Billon 2018).

Sudden changes in policy or practice further contribute to the illegibility of China's migration regime. For example, Hong Kong immigration authorities abruptly stopped accepting Gambian arrivals from Mainland China without any announced policy change. Within the mainland, renting an accommodation to undocumented migrants may be tacitly tolerated by the local PSB during some periods but clamped down on at other times (Haugen 2018). The combined lack of a transparent legal framework and policy and practice variations across space and time obstruct migrants' informed decision-making. 


\section{Interplay with management of internal migration}

Chinese discourses about undocumented migrants commonly refer to the problem of san fei, or 'the three illegals': illegal entry, illegal residence, and illegal employment (Pieke 2012). The regulation of residence is a distinctive feature of China's migration control that derives from the history of controlling internal migration. Legal instruments and institutions designed to manage internal population movement have now also become tools for implementing Chinese immigration legislation. Whereas residence certification is largely abolished for internal migrants, foreigners in hotels, dormitories, and apartments must register with the local PSB. Residence registration serves three main purposes: to turn away foreigners without valid visas, to maintain records of where foreigners live, and to keep foreigners out of designated geographic zones and cheap housing where the police denies registration.

The 2012 Exit and Entry Administration Law imposes a CNY 2,000 (USD 330) penalty if foreigners fail to register their rental housing (Ministry of Public Security 2012). Furthermore, the law makes ordinary citizens bear responsibility for enforcing China's immigration policy: under Article 45, anyone who becomes aware of foreigners who have entered, reside, or are employed illegally in China are required to notify the police. In South China, financial incentives are offered to citizens who inform on people who house or employ undocumented migrants (Guangdong Government 2011). These developments imply a double displacement of borders that can be observed in many parts of the world: border control is dispersed and shifted away from the nation's outer edges, and the responsibility for monitoring the border is increasingly placed on nonstate actors (cf. Guiraudon and Lahav 2000). The decentralisation and privatisation of enforcement of immigration control renders migration control less predictable and more contingent on local circumstances.

\section{Networked entrepreneurship}

The immigration regime aside, foundations to maintain a livelihood in China present African migrants with particular opportunities and challenges. It is primarily the export of Chinese manufactured goods to Africa that underpins the African presence in Guangzhou, directly or indirectly. Many African residents run trading businesses in collaboration with relatives or business partners in Africa; others provide services to visiting merchants. There is a symbiotic relationship between the many short-term 
African visitors and the comparatively few long-term African residents (Mathews, Lin, and Yang 2017; Lan 2017).

African newcomers without capital may find a more settled person who provides their pocket money in return for help with packing goods and running errands. Such stopgap arrangements can be important as migrants seek to enter the trading economy. Doing so requires a large network of potential customers at home as well as acquaintances in China who can guide them to the right suppliers and efficient logistics providers. In other words, gaining a foothold in China represents an extreme case of the more general argument about the strength of weak ties (Granovetter 1973; Dekker and Engbersen 2014). Even well-to-do Africans in Guangzhou continue to rely on a broad set of relations throughout their stay for their businesses to remain successful.

\section{'A stepping stone to anywhere'}

The trading business holds promise of international mobility. Circular migration and the maintenance of social relations in both places of origin and destination is an ideal scenario for migrants in various parts of the world. Migrants typically earn money in the country of destination and divide their investments between the societies of origin and destination. In China, investment opportunities are severely curtailed by restrictions on foreign ownership. At the same time, circulation is as much a business necessity as a social aspiration. Successful African entrepreneurs with Chinese residence permits tend to travel frequently in order to manage at one end of the business, sourcing and export, and at the other, import and wholesale.

Those who lack social networks and skills to succeed in business may see China as a stop en route to more desirable destinations where wage work is available. 'I can use China as a stepping stone to anywhere,' a Gambian man said hopefully. Some planned all along to use China to reach other destinations, while others realised only after they arrived that wage work is hard to come by. For many, China unintentionally becomes the end point of their migration trajectory. For others who leave while their Chinese visa is still valid, a feasible onward journey is to explore opportunities in Malaysia, Thailand, or elsewhere in South-east Asia.

\section{Barriers to exit}

The Chinese immigration legislation passed in 2012 was entitled the 'Exit and Entry 
Administration Law of the People's Republic of China' (Ministry of Public Security 2012). The equal emphasis given to exit and entry reflects the tight control over departures for much of the PRC's history. Only since 1985 have foreigners with valid Chinese visas been able to leave the country without applying separately for an exit visa (Liu 2009).

Currently, foreigners face severe barriers to exit if they overstay their visa. To leave China, they must obtain an exit permit from the PSB. Occasionally, exit-visa applicants have been imprisoned for immigration offenses after having approached the PSB to apply for an exit permit. More commonly, the PSB instructs prospective applicants to prepare a number of documents, with requirements varying across PSB branches. In Guangzhou, exit-visa applications require a valid passport, a prepaid plane ticket, proof of payment of a CNY 10,000 fine, and residence registration.

Paradoxically, the residence registration can only be acquired by foreigners with a valid visa. The catch-22 situation deters many undocumented migrants from applying for exit permits in Guangzhou, pushing them towards other administrative regions. Complicated regulations and divergent practices have created a market for informal brokerage of exit permits. Rather than seeking the services of expensive and unreliable brokers, many undocumented migrants with a desire to leave China remain until they are intercepted, incarcerated, fined, and deported at their own expense.

Having reviewed key aspects of the Chinese context, we now examine the dynamics of circumstantial migration as it is expressed in our material on Gambian migrants.

\section{Latency and circumstance}

When migration is circumstantial, it defies explanation with reference to particular causes. However, circumstantial turns often unfold against a backdrop of latent influences. For Gambians in China, three such influences stand out.

The first is the widespread migration aspirations in West Africa. The Gambian informants we encountered in China and the Gambia came from social environments where the quest for international migration is entrenched (cf. Gaibazzi 2012). The barriers to migration from West Africa are overwhelming, and many people-young men especially - therefore find themselves in a situation of involuntary immobility (Carling 2002). When individuals live with a desire to leave, a momentary opportunity 
can trigger an unplanned departure (Åkesson, Carling, and Drotbohm 2012; Boccagni 2017).

In most cases, young Gambians' migration aspirations remain unfulfilled. Yet, the departures of a few keep the dream of migration alive for many others. Unexpected and unannounced departures add to the anticipatory sense of possibility among those who remain. The implication is that you must be prepared. 'You have to file a passport,' said Jatta, one of the Gambian returnees, 'even if you don't plan to travel. You have to be ready if something comes up.'

This 'be-ready' mode illustrates the interaction of agency, structure, and circumstance in migration processes. Socioeconomic, cultural, and geopolitical structures go a long way in explaining the migration aspirations of Jatta and his peers. Furthermore, the migration regime affects migration patterns, including the containment imposed through visa requirements, carrier sanctions, and border controls. The young men's agency is expressed in their capacity to aspire (Appadurai 2004), as well as in strategic actions, such as obtaining a passport. Actual departures, though, are also products of circumstance; opportunities to leave present themselves serendipitously to some Gambians, but not others.

The collective anticipation of migrating may override individual preferences. Findings from a survey in neighbouring Senegal corroborate this point (Carling et al. 2013). Respondents were asked if they would prefer to move abroad or to remain in Senegal. They were also presented with the scenario of being given the necessary papers to go to Europe and asked if they would go or not. A third of the people who had preferred to remain still said that they would seize the opportunity to go to Europe. This paradox arose because migration overseas was so communally coveted that failing to seize such an opportunity would be a social liability. It also illustrates the scope for circumstance in determining timing, destination, and conditions of migration.

China was not the preferred destination for the Gambians. From a Gambian perspective, China occupies the middle tiers of what Paul (2011) calls a hierarchy of destinations: more attractive than regional destinations such as Senegal and Angola, yet inferior to the United States and Europe. Several of the informants had tried to go to Europe, which typically means travelling first to another West African capital to 'look for a route' (Gaibazzi 2015a). Upon returning to the Gambia from China, Jatta explained that he initially went to Dakar, Senegal, intending to travel to Europe. Upon losing the money he had brought to finance this journey, he was approached by an agent 
offering to arrange for a less expensive Chinese visa. The agent was a relative, and given that he had already left the Gambia with the intention to emigrate, Jatta took up the agent's offer.

Once in China, Hadim, another informant, and many other Gambians discovered a reality that challenges the notion of hierarchically ordered destinations: China offered opportunities for Gambians of a certain socioeconomic position, but not for all. As one Gambian put it: 'China is designed in such a way that you cannot earn anything there. You can buy goods and earn money from selling them in your own country, but you cannot earn anything in China.' Indeed, the only source of income some of the Gambians found was working as errand runners, cleaners, or helpers for other West Africans. On top of the challenge of survival in China, there was a stigma attached to not being able to find a job after successfully having emigrated. 'What people think,' one informant explained, 'is that you are sitting around because you are too lazy to find a job.'

A second latent influence is the complications of leaving China. Many Gambians ended up overstaying their visas, often as the result of a circumstantial turn of events. A number of them tried to move on to Hong Kong, but were denied entry or deported to the mainland after a short stay there. At that point, their Chinese visas had expired or were about to. Others simply had no return ticket, since the agents who brought them to China commonly cancelled the return immediately after their clients had arrived. Some Gambians overstayed simply by failing to take action in time. These pioneers in a new migration flow were oblivious to the extreme difficulties of being undocumented in China.

Like the initial force of pursuing emigration, the quest to get unstuck in China took unforeseeable turns. One example was the switch to being asylum-seekers. None of the Gambian informants left their home country with the intention to seek asylum, but in China this emerged as a possible way out of overstaying. In practice, seeking asylum meant travelling to Beijing, 1,900 kilometres away, and requesting an interview with the UN Refugee Agency (UNHCR). A backlog of cases meant that the interview itself would take place about six months after the request. One Gambian believed that he was protected by his interview appointment slip. He showed it to the police upon being stopped on the street in Guangzhou and declared 'this is my asylum.' Back in the Gambia, he told Haugen how his heart had sunk when the police had replied 'this is nothing, we don't allow this sheet.' He was detained and spent several weeks in jail 
before repatriation, being but one of several Gambians detained in Guangzhou while waiting for UNHRC to process their application. In another case, a Gambian man was warned by UNHCR staff in Beijing that he would risk arrest in the months prior to his appointment. He then decided to pursue a student visa instead.

The experiences of seeking asylum illustrate the illegibility of the migration regime that the Gambians sought to navigate. The unpredictability was confounded by their own limited experience and understanding of Chinese and international migration legislation. At the same time, each case exemplifies how migrants' agency co-produces the circumstantial outcomes.

A third latent influence on the Gambians' circumstantial migration was the stigma of empty-handed return. Several factors combine to place great pressure on returnees: overseas migration is a scarce and coveted opportunity; family members and relatives have often contributed to financing the migration; and the potential benefits of migration are highly visible through migrants' construction projects, investments, and gifts. In such contexts, returning with nothing to show or share can be a painful and humiliating experience (Hernández-Carretero 2016; Haugen 2012). Two of the Gambian returnees from China were called 'cowards' for coming back. 'People say you are afraid. They can ruin your reputation and ruin your life. You come back with stress, and people put more stress upon you,' one of them said. Avoiding a humiliating return had a powerful influence on circumstantial twists in migration trajectories. After disappointment in China, some pursued onward journeys to other Asian countries. Thailand, for example, was believed to offer chances for obtaining a visa for a more desirable destination. Those who went to Thailand found that the country neither provided employment opportunities nor ways to obtain visas. In a last attempt to avoid the stigma of returning from abroad without any money, many Gambians remained in Dakar on their way back from China, rather than travel home to the Gambia. Their hope was to find a way to re-emigrate that would eventually allow for a dignified return.

\section{Engagement with circumstance}

Circumstantial migration involves and requires a specific form of agency on the part of migrants: improvisation in response to shifting challenges and opportunities. Even as migrants are stimulated by overarching or latent motivations, pursuing them under volatile circumstances requires agility more so than meticulous planning. 
Such agile manoeuvring of a marginal position is common in the form of 'hustling' within and beyond the context of migration. The notion of hustling signifies 'an assemblage of everyday struggles, dealings, and opportunistic practices in the absence of formal institutional support' (Thieme 2017, 3). Such struggles defined the Asian sojourns of many of the Gambians. Given the obstacles to navigating the local economy, hustling was mainly concentrated to the circuits of other foreigners.

For example, one young Gambian, Osman, recounted two contrasting experiences of hustling in China. In one incident, a wealthy African woman needed help with a car key that broke inside the lock. Osman and a friend managed to find someone who could fix it for a set price. They deliberated whether to mark up the fee when they told the woman how much it cost or to tell her the actual price and leave it to her to reward them. On Osman's initiative, they decided on the latter. The woman gratefully gave them more than USD 100. 'You are very good in the brain!' the friend exclaimed. Osman replied: 'This is Asia - if you are not good in the brain, you will be the next victim.'

The emphasis on perceptive skilfulness, rather than moral conviction, comes through in the other experience that Osman described. An Arab man had signalled to him on the street in Guangzhou that he wanted to buy marijuana. Osman told the man to give him the money, and that he would fetch the drugs. 'He gave me 150 RMB. I took the money and left. If he waited there from sunset to sunrise, he still would not see me,' Osman said laughingly. The two stories illustrate a key aspect of hustling as a form engagement with circumstance: it is not simply about seeing opportunities and seizing them, but about knowing how — at the right moment — to seize them.

Hustling is also descriptive of the migration trajectory as a whole. Going to China was, as we have described, about seizing an opportunity that appeared to be the best next step forward as well as adjusting to setbacks along the way. The migrants were conscious of the vastly different outcomes of migration to China, and they had many thoughts about what it took to succeed. When interviewed, they portrayed success as neither a meritocratic outcome, nor contingent on personal privilege and connections. Rather, success rested above all on a match between the migration destination and one's personal destiny. This was illustrated by Omar's description of his stay in Guangzhou after being denied entry to Hong Kong. He did not believe he could do well, which he expressed by saying: 'I knew that this place... maybe it's not my destination.' His choice of words reflects the complex relationship between earthly action and divine 
destiny in Islam. Predestination in Islam, argues Elliot $(2016,497)$, is not a fatalistic backdrop, but rather an inspiration for acting 'in specific, hopeful ways, in view of a future that has already been written'.

Among the Gambians, accounts of success or failure were also described with an emphasis on luck. A recurrent theme in which luck came up was the contrast between Hong Kong and mainland China. 'In Hong Kong, you might be lucky,' one man said. 'It's not 100 percent sure, but you might be lucky. In China, it's not possible to be lucky.' His description underlined the limitations of individual agency in the sense that, even in Hong Kong, making it is ultimately a question of luck. At the same time, his account emphasised the necessity of trying to enter Hong Kong. It explains the frustrations of those who were excluded from the place where luck was presumed to exist.

The process of entering Hong Kong was itself described as a matter of luck. The element of luck was important also when migration brokers were paid to facilitate the entry; working through an effective broker is itself a fortunate event. Religious and culturally specific nuances matter: in the Gambia, luck is not understood simply as a random, impersonal event; it is part of a person's destiny and invites quests to seek one's fortune (Gaibazzi 2015b).

\section{Mediation of circumstance}

Migrants' subjection to circumstance creates a space for brokerage that helps exploit opportunities and overcome obstacles. The dynamics of brokerage in circumstantial migration can thus be understood as a particular form of migration facilitation. At the same time, attention to the role of brokerage also illuminates how circumstantial migration figures in diverse migration categories, including refugee migration and contract labour migration (cf. Alpes 2017; Gammeltoft-Hansen and Nyberg Sørensen 2013; Cranston, Schapendonk, and Spaan 2018; Reeves 2016). Scholars have embraced the terms 'migration brokers' and 'migration industries' as labels for a range of services that have functional similarities, yet take diverse legal, semi-legal, and illegal forms.

Brokers command knowledge, skills, networks, or influence that can be mobilised to help prospective migrants overcome obstacles. Their services can be provided against a variety returns that may include combinations of monetary payments, sexual benefits, social prestige, and altruistic desires to help. Depending on the context, 
brokers often operate under the competing incentives of short-term gains from exploitation of individual clients and long-term gains from building a reputation as trustworthy service providers. The most effective proof of a broker's effectiveness is their ability to arrange successful departures, for example, to China. This matters more than the migrant's eventual success at the place of destination (Alpes 2016).

The Gambians expressed dependence on brokers at many stages of their migration trajectories in and out of China. 'It is not difficult to get the Chinese visa,' said one return migrant. 'Agents have the resources you need, the bank statements, hotel reservation, and so on.' All the Gambians we interviewed in China and the Gambia travelled with genuine passports and visas, but the visas were often obtained on the basis of false documentation - a common practice representing a low-key end of the spectrum of migrant smuggling in West Africa (Carling 2016). The extent to which the Gambians felt deceived by the brokers varied greatly: some insisted that it was immoral to bring them to an inhospitable country like China, while others said that the hardship in China was evident from the low brokerage fee and that any eventual success is beyond a broker's control.

Academic and popular accounts of migration brokerage typically figure brokers who mobilise resources for profit and migrants who instrumentally employ brokers to reach their aims. The notion of circumstantial migration complicates this picture. Brokerage in circumstantial migration introduces additional unpredictability, even as it helps migrants overcome obstacles, and it is not necessarily an instrumental transaction that is guided by the migrant's determination. The above-mentioned experience of Jatta is a case in point: his migration agent only managed to get a visa for China, not Europe or the US, and Jatta then spontaneously grasped this opportunity. In some instances, chance encounters en route shape migrants' trajectories in ways that do not reflect particular agendas (cf. Gladkova and Mazzucato 2017). In other cases, circumstantial migration is mediated by third parties with a stake in the migration project, for example, family members of the prospective migrant.

Hadim explained how the departure for China was neither his own idea nor a result of his own efforts. 'My wife wanted something better for me and for the family,' he said. 'She paid my ticket and the visa. She did everything for me to go. She was thinking that life would change, that your life will change in China'. He stressed that he did not blame his wife for the failed experience. Instead, after his return, he kept placing trust in her advice to move to another destination. 'This time, let's try America, she said 
[to me]. Europe has a little bit of the same condition as China with the police, but America is better,' he recounted her advising.

\section{Temporalities of circumstance}

Analysis of circumstantial migration can be enriched by insights from the recent temporal turn in migration studies (Baas and Yeoh 2019, Griffiths et al. 2013). In particular, it matters how circumstantial migration is simultaneously embedded in multiple temporalities at diverse scales. Our analyses of Gambian experiences point, in particular to the life-course anchoring of migration and the ambiguity of time as a menace and a resource.

The common Gambian term for a return migrant - semester - derives from a temporal expression, namely the Swedish word for 'holiday'. Scandinavia has been a main destination for migration from Gambia, and semester is now employed for anyone who has spent time abroad, including in China. Semester was previously associated with young men, often school dropouts, who emigrated and achieved wealth and social status that normally would be reserved for men of a more advanced age and class (Ceesay 2016). Migration could, in other words, be interpreted in a life-course perspective (cf. Kobayashi and Preston 2007; Bailey 2009; Findlay et al. 2015). In an age of involuntary immobility, however, most Gambians cannot travel to the countries where they believe goals can be attained. The youngest and the oldest of our informants who went to China in search of wage work were almost 30 years apart.

The Gambians' travels to China were generally not triggered by life-course events that interrupted the ordinary passing of time. Rather, they felt that time had been passing them by without bringing about opportunities for economic and social advancement. Their circumstances differed: some were married with children; others were responsible for helping their mothers and siblings and aspired to marry soon. There were men who worked low-wage jobs, owned their own taxis, helped out in their families' shops, or held university degrees that occasionally led to internships or temporary assignments. The diversity in resources and responsibilities notwithstanding, they waited for a chance to go abroad and simultaneously emphasised the value of staying busy during the wait. 'We are all hustling for our future. You don't sit,' one man noted. 
Time spent abroad takes on a different significance than time spent waiting. Time in foreign countries is meant for economic accumulation through hard work. A few of the Gambians in China found informal work as delivery boys for Senegalese cooks, who sold food to Senegalese and Gambian business people. However, most had no way to make money. They lived together in small apartments sublet by African landlords who charged rent by the day. Staying in such apartments was illegal, which made many migrants afraid to venture out on the streets, where the police might intercept them. Restricted mobility confounded their disappointment with lack of employment opportunities in China. 'Time is not waiting for no man,' one Gambian said to express his frustrations. Another described passing days without working as emasculating and deviant, exclaiming: 'A large man sitting like that, it's not normal! [...] Sitting down is good for old man, old woman, but not for youth man. It is the time you use your energy.'

The scene of inactive young men made a deep impression on Gambians who arrived in Guangzhou with the belief that their time in China would provide a chance to earn money. The situation prompted some to return to Gambia, while others promptly started to prepare for onward migration Hong Kong, Malaysia, or Thailand. Their experiences illustrate May and Thrift's (2003) point that time-space compression is not uniformly experienced. Air travel made reaching China quick and relatively easy, but the spatial displacement made their time unproductive, and the days spent inside their apartment felt long and dreary. The Gambian migrants saw their time not only losing its economic value, but also becoming morally suspect. Traders, by contrast, found that new flight connections between China and Africa helped speed up their business and enabled them to spend time more effectively.

The co-constitution of spatial and temporal understandings of the migration experience was articulated through the Gambians' expressions 'fall into overstay' and 'enter into overstay', which both denoted becoming undocumented. Space-time is understood relative to one's position. From a legal point of view, the transition from documented to undocumented is temporally induced: people are legally in a foreign country until their visa expires, after which they become irregular migrants. By contrast, from the migrants' point of view, the expiration of the visa prompted a transition that was spatial.

While they were in China, the Gambians contemplated how time worked against them at home. Expectations for what they would bring back increased the longer they 
were gone. Those who had taken leaves from their work in the Gambia were at greater risk of losing their job with every day that passed. The pressure of passing time in vain could either motivate the migrants to return or encourage their moving on to another Asian country. As one university graduate explained: 'I was stubborn. I had a chance to go back home from China straight to the Gambia. But I was hoping that if I go to Thailand... I can apply for another country.' After five months abroad, he decided to return in order for his time to regain its value. 'I reasoned: If I go back, I have something to do, something to engage myself in. For five months I didn't make anything.'

After leaving China, many Gambians reassessed the significance of the time they spent in China. They considered themselves more cosmopolitan after having concrete travelling experiences, for example, being on an airplane and dealing with jetlag. 'I cannot catch the resources and the time I spent in Asia back, but it gave me an education I cannot get in class. It was a waste before, but now it's very useful to me,' the same university graduate said, summing up his near half-year in Asia. Most of the Gambians planned to go abroad again, and believed that China prepared them to face adversities elsewhere. Passively passing time inside was reframed as useful preparation for future hardship, including, paradoxically, arduous work in other countries. The shame associated with returning as an empty-handed semester increased the resolve to leave Gambia again and prove one's ability to work hard and 'make it' in a foreign land.

\section{Conclusion: pinning down circumstantial migration}

Guangzhou is one of many unlikely transit points on Gambian migrants' trajectories in recent years. Some have ridden bicycles across the border between Russian and Norway, north of the Arctic Circle; others have struggled through the lawless wilderness on the border between Colombia and Panama. In all these places, Gambians have found have themselves among other migrants, travelling and living under the influence of circumstances they had not planned or expected. Against this backdrop, we have used the experience of Gambians in China to advance a more general argument: migration trajectories and experiences often unfold in unpredictable ways under the influence of micro-level context and coincidence. Conventional notions of structure and agency can inspire discussions of these twists and turns, but do not alone offer adequate frames of reference. The concept of circumstantial migration addresses the remaining 
gap.

Proposing a new concept for a particular form of migration raises an obvious question: how can circumstantial migration be identified? As we stressed initially, it is not a taxonomical category of migration, but a feature of migration that may be more or less prominent within migration flows. We defined it as migration trajectories and experiences that unfold in unpredictable ways under the influence of micro-level context and coincidence. Identifying this phenomenon among a group of migrants is most feasible with ethnographic and other qualitative methods. Survey methods may provide indications of circumstantial migration but are challenged by the difficulty of formulating relevant questions about the unexpected and unknowable. Indeed, accounts of circumstantial migration destabilise conceptual building blocks such as origins, destinations, and motivations that have traditionally informed migration research methods.

The idea of circumstantial migration does not explain the specific unexpected and erratic elements, but it serves as a platform for posing pertinent analytical questions. The four questions that guided each section of this article can help us understand how contemporary migration with different degrees of circumstantial migration unfolds.

First, how are latent influences triggering immediate circumstances? In our case, prominent influences were socially embedded, emotionally laden scenarios: the hopeful scenario of leaving Gambia in the first place, the dreaded scenario of returning emptyhanded, and - among those who were well-informed - the feared scenario of being stuck illegally in China. Identifying these influences contributes greatly to making sense of circumstantial turns that, in their own right, seem erratic or perplexing.

Second, how do migrants engage with volatile circumstances? The notion of circumstantial migration reflects the limited scope for making and following a specific plan. Yet, this does not mean that migrants are passively subjected to external forces. Rather, the situation requires particular forms of agency, agility, and improvisation. Our argument thus has parallels with the criticism of 'forced migration' as a concept that misrepresents human actors (Lubkemann 2008; Erdal and Oeppen 2018).

Third, how are circumstances mediated through brokerage? Pointing to the role of brokers in migration is not new, but the notion of circumstantial migration presents brokers in a different perspective: less as actors who behave and are used instrumentally and more as an additional source of unpredictability in the migration process. Brokers fulfil this role not only because of the potential for deception or exploitation, but 
because of the frequent randomness of whom one encounters and which networks or resources that person has. Shifting attention from brokers as actors to brokerage as a process is valuable for capturing the diversity of mediation.

Fourth, how does circumstantial migration produce particular temporalities? Asking this question can add value to the recent surge in analyses of the temporal dimensions of migration (see e.g. Baas and Yeoh 2019). Circumstantial migration is not only conditioned by the temporalities of migration control; diverse experienced temporalities can be juxtaposed within migrants' turbulent trajectories and, as we have shown, acquire different meaning over time.

Most of the Gambians who came to Guangzhou had a truly difficult experience, and their hardship was largely an outcome of circumstantial migration. Yet, circumstantial migration need not manifest itself in this way. Not far from the Gambians' squalid quarters are bars, restaurants, and housing complexes that cater to other segments of Guangzhou's strikingly diverse population of foreigners (see Cai and $\mathrm{Su}$, this issue). Many enjoy a comfortable standard of living but have also, like the Gambians, come to Guangzhou in unpredictable ways under the influence of microlevel context and coincidence. Unlike New York or Paris, for instance, Guangzhou is not a city that glows in the imagination of many would-be migrants. Yet it is a city where opportunities appear and are seized —or slip away. Circumstantial migration is a concept that resonates with diverse migration experiences in China. It illustrates China's fertile empirical field for advancing migration theory.

\section{References}

Åkesson, Lisa, Jørgen Carling, and Heike Drotbohm. 2012. "Mobility, moralities and motherhood: navigating the contingencies of Cape Verdean lives." Journal of Ethnic and Migration Studies 38 (1):237-60. doi: 10.1080/1369183X.2012.646420.

Alpes, Maybritt Jill. 2016. Brokering High-risk Migration and Illegality in West Africa: abroad at any cost: Taylor \& Francis.

2017. "Why aspiring migrants trust migration brokers: the moral economy of departure in Anglophone Cameroon." Africa 87 (2):304-21. doi: 10.1017/S0001972016000978. 
Appadurai, Arjun. 2004. "The Capacity to Aspire: Culture and the Terms of Recogniton." In Culture and Public Action, edited by Vijayendra Rao and Michael Walton, 59-84. Stanford: Stanford University Press.

Baas, Michiel, and Brenda SA Yeoh. 2019. "Introduction: Migration studies and critical temporalities." Current Sociology 67 (2):161-8. doi: $10.1177 / 0011392118792924$.

Bailey, Adrian J. 2009. "Population geography: lifecourse matters." Progress in Human Geography 33 (3):407-18.

Bakewell, Oliver. 2010. "Some Reflections on Structure and Agency in Migration Theory." Journal of Ethnic and Migration Studies 36 (10):1689-708.

Bertoncello, Brigitte, and Sylvie Bredeloup. 2009. "Chine-Afrique ou la valse des entrepreneurs-migrants." Revue Européenne des Migrations Internationales 25 (1):45-70.

Boccagni, Paolo. 2017. "Aspirations and the subjective future of migration: comparing views and desires of the "time ahead" through the narratives of immigrant domestic workers." Comparative Migration Studies 5 (1):4. doi: 10.1186/s40878-016-0047-6.

Brettell, Caroline B., and James F. Hollifield, eds. 2015. Migration Theory. Talking across Disciplines, 3 ed. New York: Routledge.

Carling, Jørgen. 2002. "Migration in the age of involuntary immobility: theoretical reflections and Cape Verdean experiences." Journal of Ethnic and Migration Studies 28 (1):5-42. . 2016. "West and Central Africa." In Migrant Smuggling Data and Research: a Global Review of the Emerging Evidence Base, edited by Marie McAuliffe and Frank Laczko, 25-53. Geneva: International Organization for Migration.

- 2017. "Visualizing the transnational connections of China's most African neighbourhood." Environment and Planning A 49 (6):1209-13. doi: doi:10.1177/0308518X17690392.

Carling, Jørgen. and Collins, Francis L. (2018) 'Aspiration, desire and the drivers of migration.' Journal of Ethnic and Migration Studies, 44(6):909-926.

Carling, Jørgen, Papa Demba Fall, María Hernández-Carretero, Mame Yacine Sarr, and Jennifer Wu. 2013. "Migration aspirations in Senegal: Who wants to leave and why does it matter?" European Policy Brief, Brussels: European Commission. 
Castles, Stephen, Hein de Haas, and Mark J. Miller. 2014. The Age of Migration. Third ed. Basingstoke: Palgrave Macmillan.

Ceesay, Ismaila. 2016. Aligners, Lovers and Deceptors: Aspirations and strategies of young urban hustlers in the Gambia. Edinburgh: unpublished $\mathrm{PhD}$ dissertation, University of Edinburgh.

Chakrabarty, Dipesh. 1992. "Provincializing Europe: Postcoloniality and the critique of history." Cultural studies 6 (3):337-57.

Chen, Kuan-Hsing. 2010. Asia as method: Toward deimperialization. Durham: Duke University Press.

Cooper, Elizabeth, and David Pratten. 2014. "Ethnographies of uncertainty in Africa: an introduction." In Ethnographies of Uncertainty in Africa, edited by Elizabeth Cooper and David Pratten. London: Palgrave Macmillan.

Conrad-Suso, C.T. 'Involuntary Immobility and the Unfulfilled Rite of Passage: Implications for Migration Management in the Gambia, West Africa.' International Migration, n/a(n/a). doi: 10.1111/imig.12675

Cranston, Sophie, Joris Schapendonk, and Ernst Spaan. 2018. "New directions in exploring the migration industries: introduction to special issue." Journal of Ethnic and Migration Studies 44 (4):543-57. doi: 10.1080/1369183X.2017.1315504.

Dekker, Rianne, and Godfried Engbersen. 2014. "How social media transform migrant networks and facilitate migration." Global Networks 14 (4):401-18. doi: doi:10.1111/glob.12040.

Elliot, Alice. 2016. "The makeup of destiny: Predestination and the labor of hope in a Moroccan emigrant town." American Ethnologist 43 (3):488-99. doi: 10.1111/amet.12341.

Erdal, Marta Bivand, and Ceri Oeppen. 2018. "Forced to leave? The discursive and analytical significance of describing migration as forced and voluntary " Jounal of Ethnic and Migration Studies 44 (6):981-98.

Fairbank, John K. 1969. "Assignment for the'70's." The American Historical Review 74 (3):861-79.

Findlay, Allan, David McCollum, Rory Coulter, and Vernon Gayle. 2015. "New Mobilities Across the Life Course: a Framework for Analysing Demographically Linked Drivers of Migration." Population, Space and Place 21 (4):390-402. doi: 10.1002/psp.1956. 
Gaibazzi, Paolo. 2012. "Home as Transit: Would-Be Migrants and Immobility in Gambia." In The Challenge of the Threshold. Border Closures and Migration Movements in Africa, edited by Jocelyne Streiff-Fénart and Aurelia Segatti, 16376. Plymouth: Lexington Books.

- 2015a. Bush Bound: young men and rural permanence in migrant West Africa. New York: Berghahn.

_ 2015b. "The quest for luck: fate, fortune, work and the unexpected among Gambian Soninke hustlers." Critical African Studies 7 (3):227-42.

Gammeltoft-Hansen, Thomas, and Ninna Nyberg Sørensen, eds. 2013. The Migration Industry and the Commercialization of International Migration. Abingdon: Routledge.

Gladkova, Nataliia, and Valentina Mazzucato. 2017. "Theorising Chance: Capturing the Role of Ad Hoc Social Interactions in Migrants' Trajectories." Population, Space and Place 23 (e1988):1-13. doi: 10.1002/psp.1988.

Granovetter, Mark S. 1973. "The Strength of Weak Ties." American Journal of Sociology 78 (6):1360-80.

Griffiths, M., Rogers, A. and Anderson, B. (2013) Migration, time and temporalities: review and prospect, COMPAS research resources paper. Oxford: Centre on Migration, Policy and Society.

Guangdong Government. 2011. 广东省外国人管理服务暂行规 (Temporary regulations for managing and servicing foreigners in Guangdong). Guangzhou: Guangdong Government Ordinance 155.

Guiraudon, Virginie, and Gallya Lahav. 2000. "A Reappraisal of the State Sovereignty Debate The Case of Migration Control." Comparative political studies 33 (2):163-95.

Haugen, Heidi Østbø. 2012. "Nigerians in China: A Second State of Immobility." International Migration 50 (2):65-80. doi: 10.1111/j.1468-2435.2011.00713.x. . 2014. "'Take Over Asia for God!': The Public Face of African Pentecostal Churches in China." In The Public Face of African New Religious Movements in Diaspora, edited by Afe Adogame, 105-24. Farnham: Ashgate. . 2018. "Residence Registration in China's Immigration Control: Africans in Guangzhou." In Destination China. Immigration to China in the Post-Reform Era, edited by Angela Lehmann and Pauline Leonard, 45-64. Heidelberg: Palgrave Macmillan. 
Hernández-Carretero, María. 2016. "Hope and uncertainty in Senegalese migration to Spain: taking chances on emigration but not upon return." In Hope and uncertainty in contemporary African migration, edited by Nauja Kleist and Dorte Thorsen, 113-33. New York: Routledge.

Hernández-Carretero, María, and Jørgen Carling. 2012. "Beyond "kamikaze migrants": Risk taking in West African boat migration to Europe." Human Organization $71(4): 407-16$.

Huang, Guangzhi. 2018. "Policing Blacks in Guangzhou: How Public Security Constructs Africans as Sanfei." Modern China 0 (0):Online first. doi: $10.1177 / 0097700418787076$.

Kobayashi, Audrey, and Valerie Preston. 2007. "Transnationalism through the life course: Hong Kong immigrants in Canada." Asia Pacific Viewpoint 48 (2):15167.

Lan, Shanshan. 2017. Mapping the New African Diaspora in China. New York: Routledge.

Liang, Kelly, and Philippe Le Billon. 2018. "African migrants in China: space, race and embodied encounters in Guangzhou, China." Social \& Cultural Geography:127. doi: 10.1080/14649365.2018.1514647.

Liu, Guofu. 2009. "Changing Chinese Migration Law: From Restriction to Relaxation." Journal of International Migration and Integration / Revue de l'integration et de la migration internationale 10 (3):311-33. doi: 10.1007/s12134-009-0105-0.

—. 2016. Chinese immigration law. London: Routledge.

Lubkemann, Stephen C. 2008. Culture in chaos. An anthropology of the social condition in war. Chicago,: University of Chicago Press.

Mainwaring, Cetta. 2016. "Migrant agency: Negotiating borders and migration controls." Migration Studies 4 (3):289-308. doi: 10.1093/migration/mnw013.

Mainwaring, Ċetta, and Noelle Brigden. 2016. "Beyond the Border: Clandestine Migration Journeys." Geopolitics 21 (2):243-62. doi: 10.1080/14650045.2016.1165575.

Mathews, G., L.D. Lin, and Y. Yang. 2017. The world in Guangzhou: Africans and other foreigners in South China's global marketplace. Chicago: University of Chicago Press.

Mavroudi, Elizabeth, and Caroline Nagel. 2016. Global Migration: Patterns, Processes, and Politics: Routledge. 
May, Jon, and Nigel Thrift. 2003. Timespace: geographies of temporality: Routledge. Merton, Robert K. 1948. "The bearing of empirical research upon the development of social theory." American Sociological Review 13 (5):505-15.

Ministry of Public Security. 2012. "Exit and Entry Administration Law of the People's Republic of China. Adopted at the 27th meeting of the Standing Committee of the Eleventh National People's Congress of the People's Republic of China."

Oumar Ba, Cheikh, and Armelle Choplin. 2005. "Tenter l'aventure par la Mauritanie : migrations transsahariennes et recompositions urbaines." Autrepart 36 (4):2142. doi: 10.3917/autr.036.0021.

Pandolfo, Stefania. 2007. "'The burning": Finitude and the politico-theological imagination of illegal migration." Anthropolocigal Theory 7 (3):329-63.

Paul, Anju Mary. 2011. "Stepwise International Migration. A Multistage Migration Pattern for the Aspiring Migrant." American Journal of Sociology 116 (6):184286.

Pieke, Frank N. 2012. "Immigrant China." Modern China 38 (1):40-77. doi: 10.1177/0097700411424564.

Reeves, Madeleine. 2016. "Diplomat, Landlord, Con-artist, Thief: Housing Brokers and the Mediation of Risk in Migrant Moscow." 34 (2):93-109. doi: 10.3167/ca.2016.340207.

Samers, Michael, and Michael Collyer. 2017. Migration. Second Edition ed. Abingdon: Routledge.

Schapendonk, Joris, Ilse van Liempt, Inga Schwarz, and Griet Steel. in press. "Rerouting migration geographies: Migrants, trajectories and mobility regimes." Geoforum. doi: https://doi.org/10.1016/j.geoforum.2018.06.007.

Thieme, Tatiana Adeline. 2017. "The hustle economy: Informality, uncertainty and the geographies of getting by." Progress in Human Geography Early view. doi: 10.1177/0309132517690039.

Zhang, Vickie. 2018. "Im/mobilising the migration decision." Environment and Planning D: Society and Space 36 (2):199-216.

Zhu, Hong and Qian, Junxi. (2020) New theoretical dialogues on migration in China: Introduction to the special issue. Journal of Ethnic and Migration Studies 